\title{
CHARACTERISTICS OF DAILY WATER TEMPERATURE FLUCTUATIONS IN LAKE KIERSKIE (WEST POLAND)
}

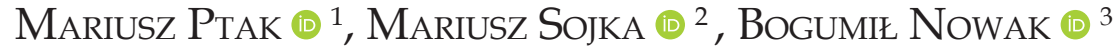 \\ ${ }^{1}$ Department of Hydrology and Water Management, Adam Mickiewicz University, Poznań, Poland \\ ${ }^{2}$ Institute of Land Improvement, Environmental Development and Geodesy, \\ Poznań University of Life Sciences, Poznań, Poland \\ ${ }^{3}$ Institute of Meteorology and Water Management, National Research Institute, Warszawa, Poland
}

Manuscript received: December 18, 2018

Revised version: July 11, 2019

\begin{abstract}
PTAK M., SojKa M., NowaK B., 2019. Characteristics of daily water temperature fluctuations in Lake Kierskie (West Poland). Quaestiones Geographicae 38(3), Bogucki Wydawnictwo Naukowe, Poznań, pp. 41-49. 8 figs.

AвsтRAст: The paper presents the dynamics of daily water temperature fluctuations in Lake Kierskie (West Poland) and determines the effect of air temperatures and wind speed on the variability of the parameter (water temperature). The analysis was based on hourly water temperature values from the period from May 2012 to January 2018. The data analysis permitted the description of the thermal regime of waters in the lake in the hourly cycle in reference to each month, and designation of months characterised by the highest and lowest stability of water temperatures. More than half of the analysed days was characterised by a change in water temperature not exceeding $1^{\circ} \mathrm{C}$. The course of water temperature showed strongly positive correlations with air temperature, and weak correlations with wind speed. Water temperatures in the lake were correlated the strongest with air temperatures with a $24 \mathrm{~h}$ time step.
\end{abstract}

KEY WORDS: lake, water temperature, air temperature, wind speed, Poznań

Corresponding author: Mariusz Ptak, marp114@wp.pl

\section{Introduction}

Research on water temperature is considered basic in the context of the functioning of lake ecosystems (Ptak et al. 2018a). Issues concerning the thermal regime of lake ecosystems are discussed in a broad spectrum in several aspects. One of them is a variable time scale involving analyses fluctuations based on multi-annual (Hampton et al. 2008), daily (Coloso et al. 2011, Choiński et al. 2015), hourly (Skowron, Piasecki 2016), or minute-based data (Choiński, Strzelczak 2018). In Poland, high variability occurs in the scope of observations of temperature in the near-surface water layer. Point measurements are dominant in the daily system, implemented for at least several decades by the Institute of Meteorology and Water Management - National Research Institute (IMGW-PIB). The hourly system of observations of lake water temperature was introduced by IMGW-PIB on selected water gauge stations several years ago. The paper is the first to present results of such monitoring in reference to Lake Kierskie (Fig. 1), where the test measurement sensor is located.

One of the greatest modern threats for lake ecosystems is the impact of climatic change, as reflected in long-term records of the course of water temperature. In a large majority of papers discussing the issue, an increase in water temperature is 


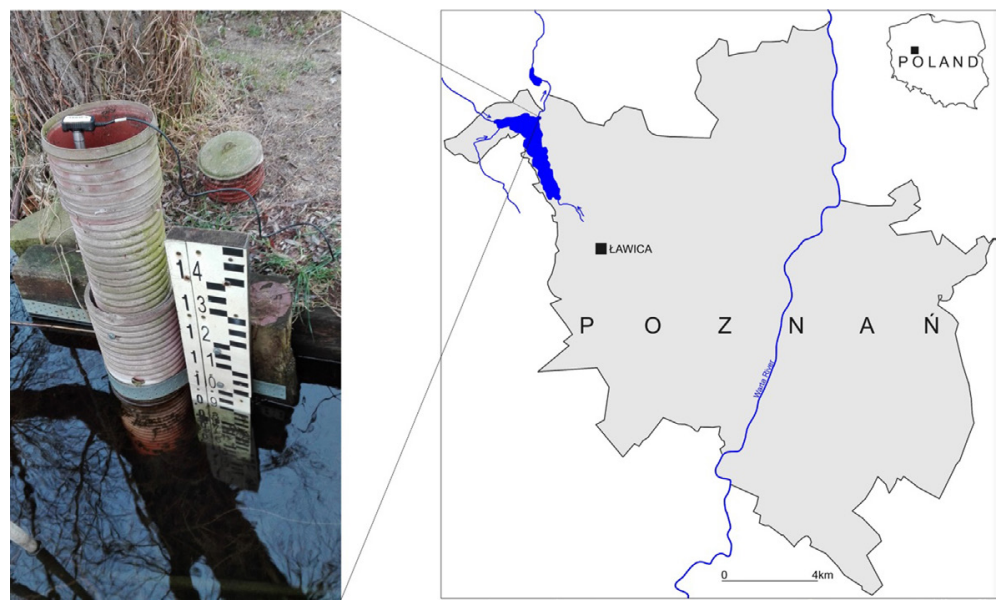

Fig. 1. Study site location. On the left: measurement site (limnimetric column and water gauge).

evident (Naumenko et al. 2006, Austin, Colman 2007, Schneider, Hook 2010, Ptak et al. 2017, Ptak et al. 2019), and the scale and rate of the process are dependent on a number of co-occurring factors (climatic conditions, surroundings, lake morphometry, etc.). The transformation of surface waters resulting from climate changes is already evident (Mooij et al. 2008, Jeppesen et al. 2012), and with the maintenance of the current trend further transformations will proceed, with largely unpredictable effects (Czernecki, Ptak 2018). Such a situation will certainly force undertaking corrective measures reducing the effects of global warming for the functioning of lake ecosystems. Such measures are only performed in the case of rivers (Ptak 2018, Ptak et al. 2019). Each expansion of knowledge in the scope of the thermal regime of lakes and its changes may contribute to the determination of the directions and scope of measures allowing for limiting the effect of climate change in the context of the functioning of lakes. The study aims at filling the gap in reference to lakes in Poland, where research at such a time scale have been rare.

The objective of the paper was to present the dynamics of daily water temperature fluctuations in Lake Kierskie, and to determine the effect of selected meteorological (wind and air temperature) components on its variability.

\section{Study site description}

Lake Kierskie is located in West Poland within the administrative boundaries of Poznań. It is a post-glacial channel lake with a surface area of $283 \mathrm{ha}$, volume of 30.8 million $\mathrm{m}^{3}$, maximum length of $4.50 \mathrm{~km}$, maximum with of 1.06 $\mathrm{km}$, maximum depth of $36.4 \mathrm{~m}$, mean depth of $10.9 \mathrm{~m}$, and shoreline of $11.960 \mathrm{~m}$ (Grześkowiak, Szymański 2009). The lake basin includes the main basin extending along the N-S axis, with variable bottom relief with numerous thalwegs and shallow areas, and a very shallow bay extending west from the main basin. Four larger rivers flow into the lake, the largest being Samica Kierska, flowing into the lake in its north-western part. The same river drains the lake, and flows out in its northern part. The shores of the lake are of very variable character - from steep scarps rising a dozen metres above the lake to flat marshy plains extending up to several hundred metres from its shoreline. To the north, west, and south, permanent and seasonal housing development is adjacent to the lake, as well as numerous marinas and recreational resorts.

\section{Materials and methods}

The paper presents hourly water temperature values from May 2012 to January 2018. A total of 49,752 records were obtained. The measurements were performed on the water gauge station of IMGW-PIB Poznań-Kiekrz, located on the northern shore of Lake Kierskie. The temperature measurements employed an OTT Orpheus mini recorder. The measurement sensor was located in the pipe mounted on the shore near the water gauge (Fig. 1). Due to the assembly possibilities, the sensor was mounted at a constant height, which translated into variable depth of 
its immersion. Depending on the water level and waves, it was located at a depth from 0.2 to $0.8 \mathrm{~m}$ below water level in the lake. The assessment of meteorological conditions employed measurement data covering air temperature and wind speed obtained from the airport meteorological station Poznań-Ławica (approximately 6 $\mathrm{km}$ south of the observation point). The measurements were performed every three hours. The characteristics of the thermal regime of water in Lake Kierskie are presented in reference to particular months. Averaged hourly courses of water temperature were determined for each month. They permitted the determination of the time of occurrence of minimum and maximum values and determination of the dynamics of their changes. The obtained results were analysed in the context of air temperature and wind speed. For the purpose of assessment of meteorological parameters on the dynamics of water temperature, the correlation analysis was performed between water temperatures in particular months and air temperatures and wind speeds. The analysis was performed on measurement data from 0:00 am, 3:00 am, 6:00 am, 9:00 am, 12:00 am, 3:00 $\mathrm{pm}, 6: 00 \mathrm{pm}$, and 9:00 pm. The correlation analysis involved the application of (advance) time shift of air temperature and wind speed respectively by $3,6,9,12,15,18,21$, and $24 \mathrm{~h}$. Finally, the development of a model was attempted for the purpose of prediction of temperatures in Lake Kierskie based on air temperatures and wind speeds. For this purpose the multiple linear regression (MLR) analysis were carried out of water temperature against the air temperatures and wind speeds measured at the same time as water temperature, and with a time step of 3,6 , $9,12,15,18,21$, and $24 \mathrm{~h}$. To setup the regression model the data from 2012 to 2018 are considered for the analysis out of which from period 2012 to 2016 are treated for the training the MLR and the remaining data from 2017 to 2018 are designed for testing the model. The statistical analyses were performed in Statistica 13.1 software.

\section{Results}

Water temperatures in Lake Kierskie in the period from May 2012 to January 2018 varied from 0.6 to $28.6^{\circ} \mathrm{C}$, with a mean value of $12.4^{\circ} \mathrm{C}$

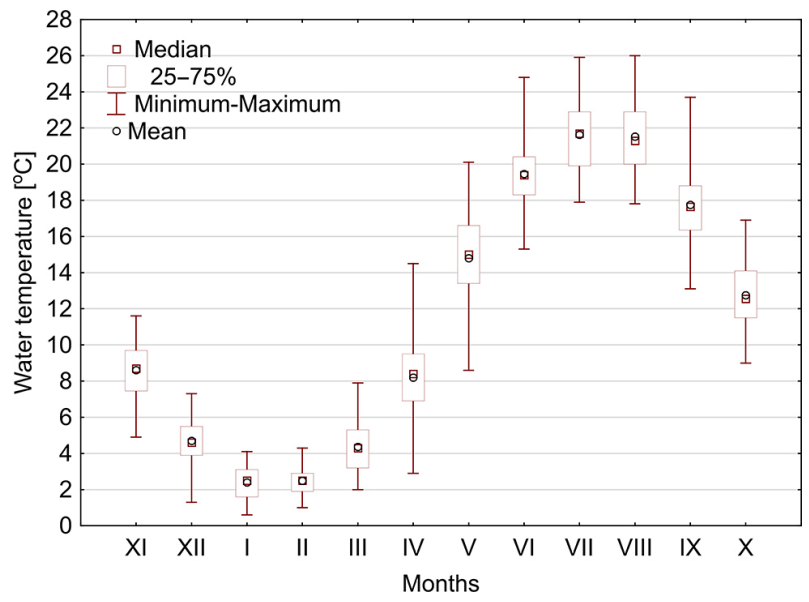

Fig. 2. Hourly changes of the lake's water temperature in individual months.

and median of $11.9^{\circ} \mathrm{C}$. The highest monthly water temperature was recorded in July - averaging $22.3^{\circ} \mathrm{C}$, and the lowest one in January - averaging $2.4^{\circ} \mathrm{C}$. The highest variability of water temperatures was observed in April, and the lowest in February (Fig. 2).

The hourly course of water temperatures in Lake Kierskie in reference to particular months is presented in Figure 3.

Averaged daily water temperature fluctuations in the monthly cycle varied from approximately $0.2^{\circ} \mathrm{C}$ (January, December) to $2.6^{\circ} \mathrm{C}$ (May). From April to December, daily maximum temperature was reached around 4:00 pm (3:00 pm GMT), in March at 2:00 pm (1:00 pm GMT), and in January and February at 1:00 am (0:00 GMT). The lowest hourly temperature fluctuations in winter months particularly result from the occurrence of ice cover isolating the waters from the effect of external factors (air temperature, wind, and insolation). The highest dynamics of water temperature fluctuations in a day were observed in the period from April to September. Hourly values of temperature fluctuations in the period reach values of more than $1.4^{\circ} \mathrm{C}$. It results from the developed thermal stratification due to which a smaller layer of water (epilimnion) is under the influence of atmospheric conditions. The response of the lake to the incoming and emitted streams of heat is then faster.

The detailed analysis of particular days points to high water temperature stability. Throughout the multi-annual period, in only 11 cases daily differences were higher than $5^{\circ} \mathrm{C}$, reaching the maximum on 13 June $2015\left(6.1^{\circ} \mathrm{C}\right)$. In the case 


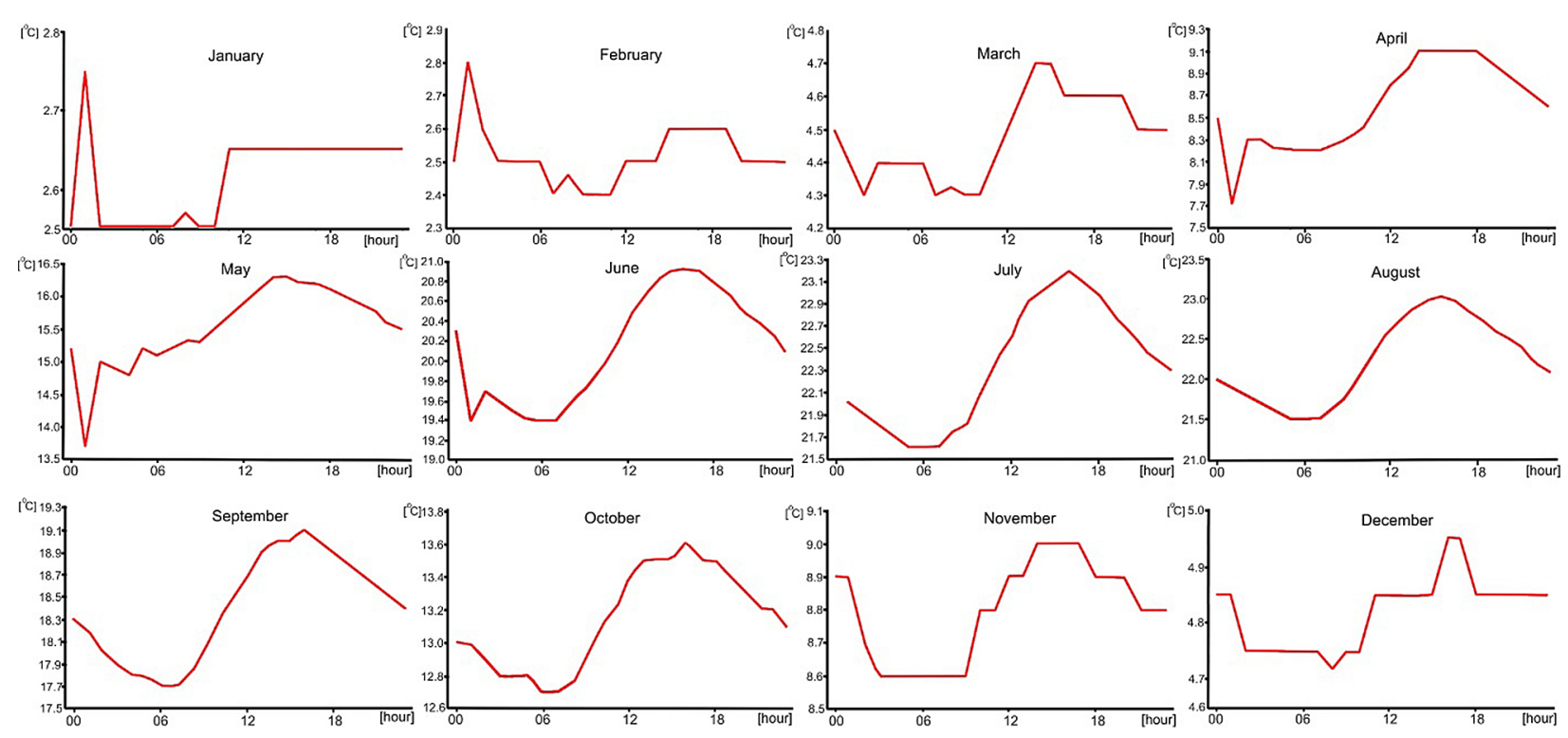

Fig. 3. Daily course of water temperature in Lake Kierskie in the monthly cycle (mean value from the years 2012-2018).

of 26 days (1\%), the changes were higher than $4^{\circ} \mathrm{C}$, in $5.5 \%$ of cases they were higher than $3^{\circ} \mathrm{C}$, in $14 \%$ of cases they were higher than $2^{\circ} \mathrm{C}$, and in $26 \%$ of cases higher than $1^{\circ} \mathrm{C}$. More than half $(52 \%)$ of all days was characterised by daily water temperature fluctuations not exceeding $1^{\circ} \mathrm{C}$, and in the case of 23 days, no water temperature fluctuations were recorded. Daily water temperature fluctuations are presented in Figure 4. The highest daily water temperature fluctuations were observed in April, and lowest in February (Fig. 5).

The next stage involved the determination of the effect of selected meteorological parameters on water temperature fluctuations. Current research points to the important role of air temperature (Ptak, Nowak 2016, Zhu et al. 2018). An example dependency between monthly water temperatures and air temperatures is presented in Fig. 6. Skowron and Piasecki (2016) dipict that these relations are mainly determined by the morphometry of lake; especially the average depth, the lake surface, and geometric depth indicator.

Another important factor affecting the thermal regime of lakes is wind. Magee, Wu (2017) analysed the response of temperature in three lakes with different morphometry to climatic changes.

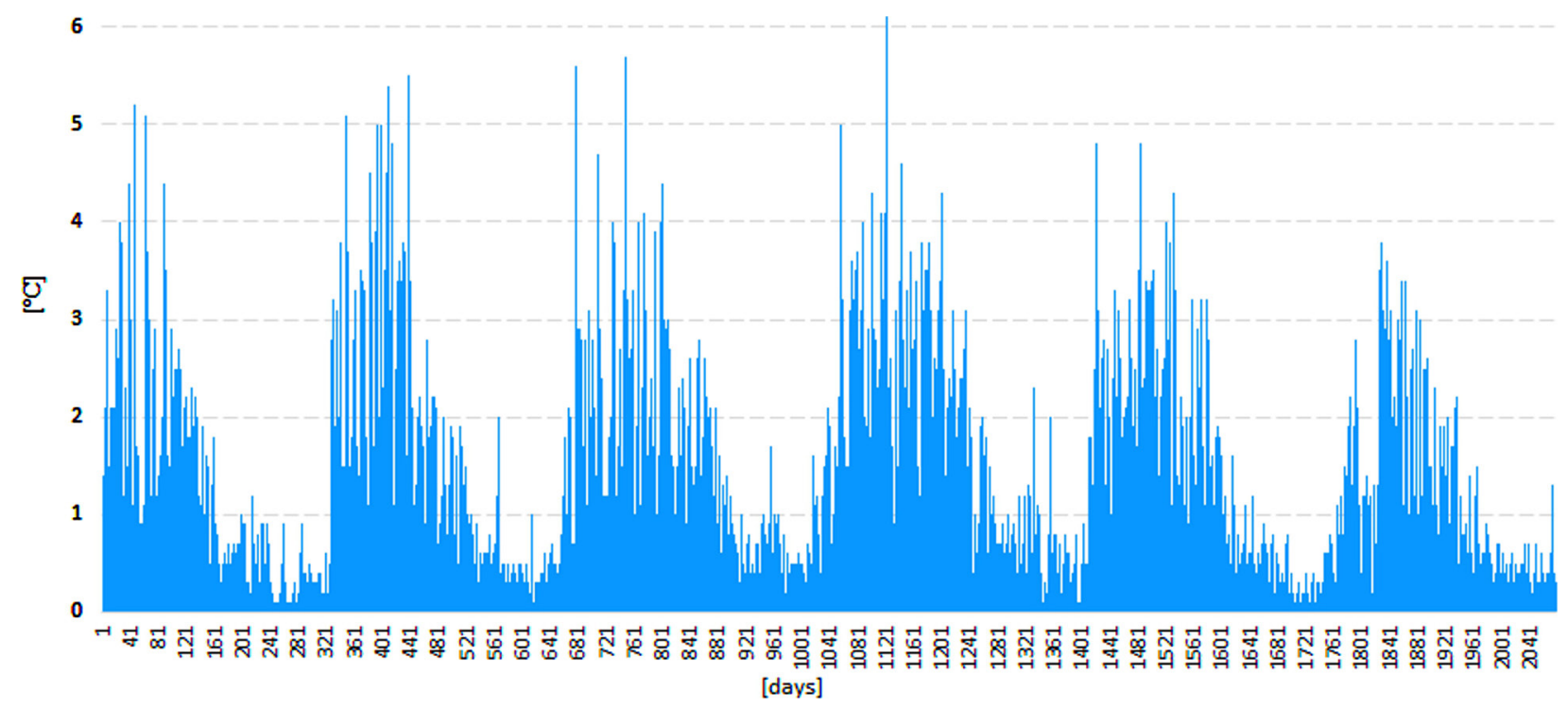

Fig. 4. Daily water temperature fluctuations in Lake Kierskie (May 2012-January 2018). 


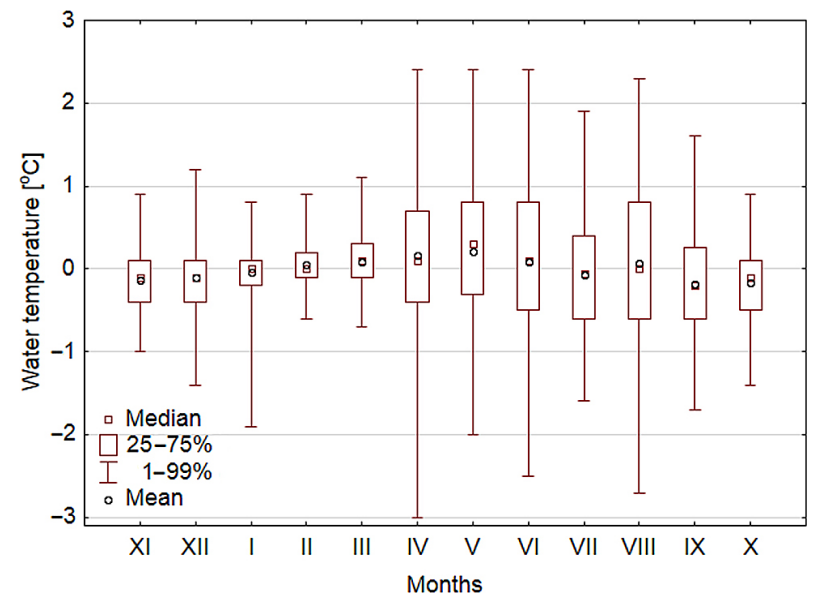

Fig. 5. Daily water temperature fluctuations in Lake Kierskie in particular months.

The authors emphasise that wind can strengthen or mitigate the impact of higher air temperatures on the thermal structure of the lake, depending on the direction of local changes in its speed. In the case of Lake Võrtsjärv (Estonia), Woolway et al. (2017) determined that decreasing wind speed values caused considerable changes in the stratification dynamics. Based on research on nine lakes in Denmark, Martinsen et al. (2019) fund that the probability of stratification by day

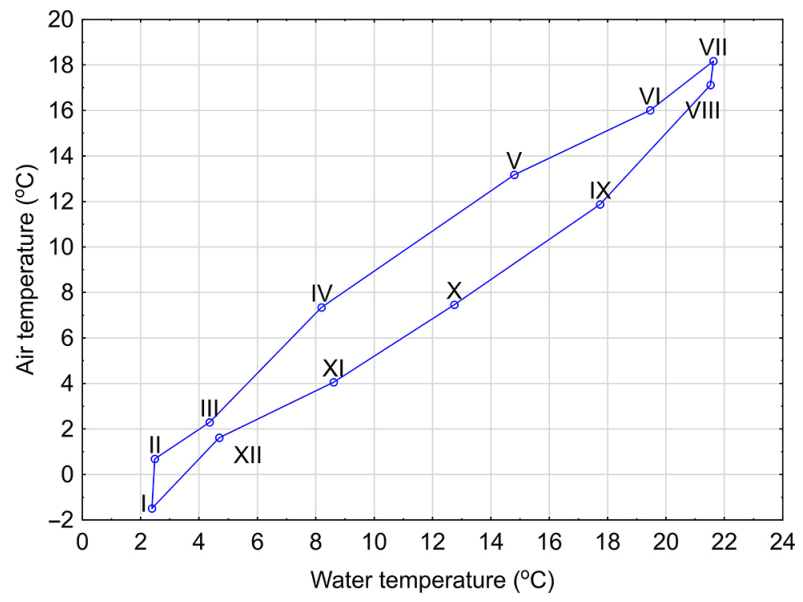

Fig. 6. Relationship between monthly average water temperature and monthly average air temperature.

increased with higher intensity of solar radiation, higher air temperature, and lower wind speed. The course of both meteorological parameters on the background of water temperature distribution in the analysed multi-annual period is presented in Figure 7.

In the first case, water temperatures as well as air temperatures were characterised by similar cyclical variability. Due to the properties of water, the course of its temperature shows lower
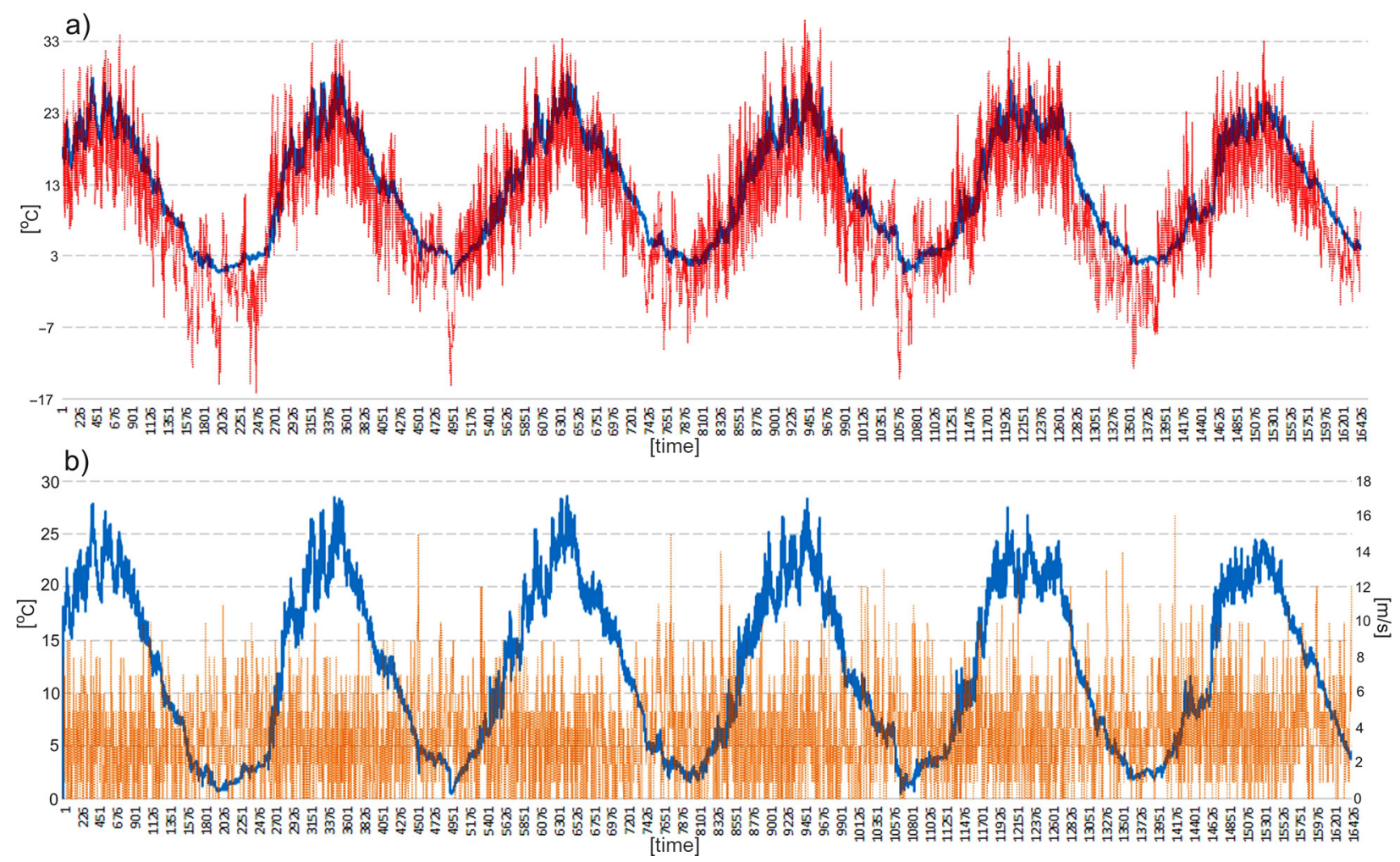

Fig. 7. Course of water temperature (blue lines) in Lake Kierskie and a) air temperature (red line) and b) wind speed (orange line) for station Poznań-Ławica in 3-hours interval (May 2012-January 2018). 
variability (lower thermal conductivity) than the course of air temperature observed in the same period. The correlation of both variables is high, and equals 0.85 . In the case of wind speed, the correlation is considerably lower, and the correlation coefficient equals -0.11 . Next, the effect of air temperature and wind speed fluctuations on water temperature fluctuations was determined, as presented in Figure 8.

The analysis of measurements from the same times showed that in the case of air temperature and water temperature, the correlation was moderate, and equalled 0.34 . In the case of wind, the correlation was negative, and equalled -0.12 . Further analyses involved the determination of correlations of water temperature fluctuations with earlier air temperature and wind speed fluctuations. Such measures were performed with a $3,6,9,12,15,18,21$, and 24 hour tie step. The analysis shows the strongest correlations of water temperature fluctuations with air temperature with a $24 \mathrm{~h}$ time step. The strongest correlations between water temperatures and air temperatures $24 \mathrm{~h}$ in advance were observed in March and November, and the weakest in February. In the case of wind, its impact was less significant, and depending on the month, the strongest correlations were observed with a 3, 9, 12, 15, and 24 hour time step. The multiple regression analysis permitted the development of prediction models for water temperatures every three hours based on water temperatures and wind speed. The development of the model employed water temperatures and air temperatures with 3, 6, 9, 12, 15, 18, 21 , and 24 hour time step. The developed models usually show low prediction capacity. Values of determination coefficients vary from 0.13 to 0.57 . The lowest values of determination coefficients were obtained for January and February, averaging 0.17, and the highest in March and
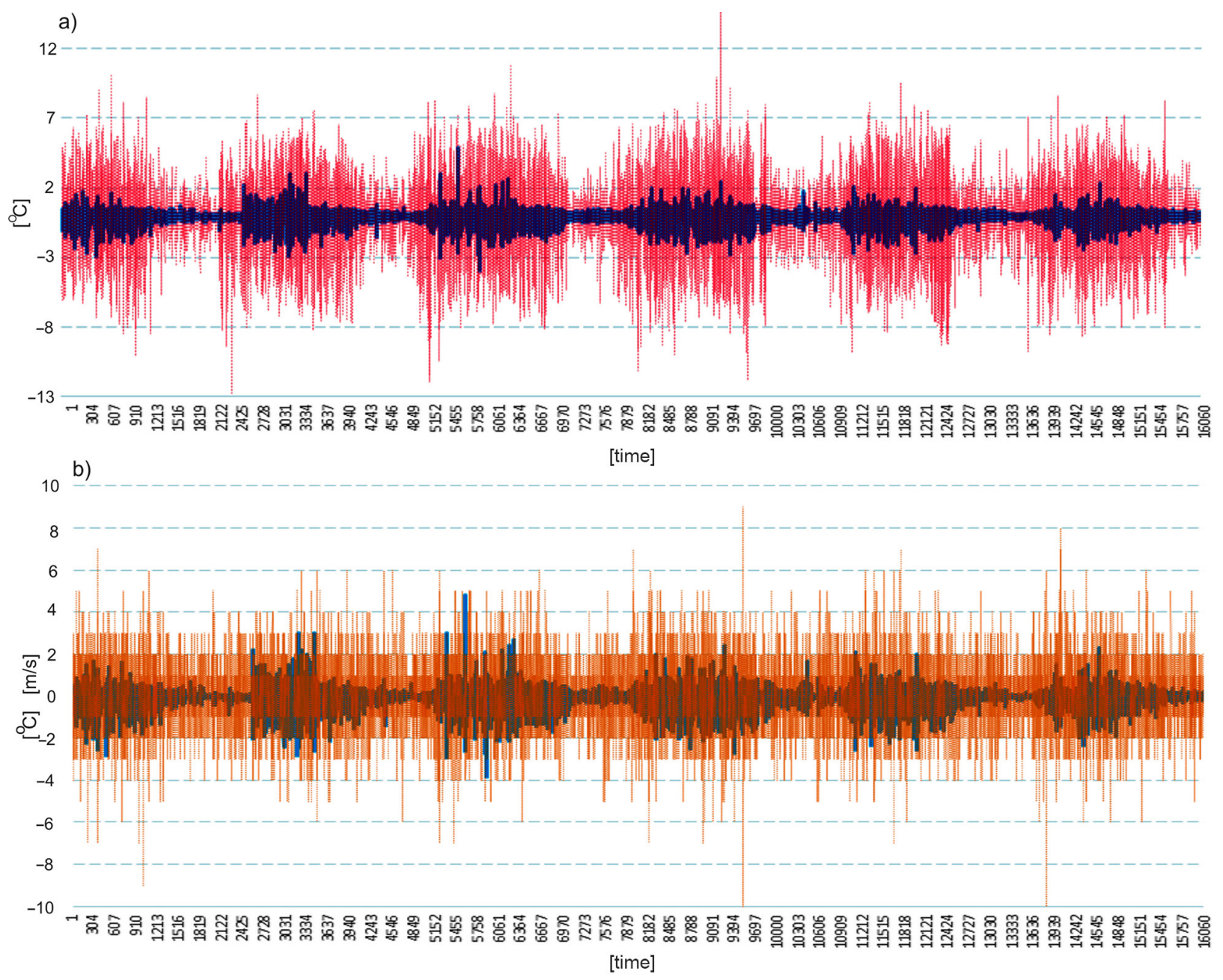

Fig. 8. Water temperature fluctuations in Lake Kierskie (blue lines) and a) air temperature (red line) and b) wind speed fluctuations (orange line) for station Poznań-Ławica in 3-hours interval (May 2012-January 2018). 
September, respectively 0.57 and 0.48 . The prediction capacity of the model can be considerably improved by introducing information on water temperature from previous time steps $i-3 h$ and $i-6 h$ to the model. This permits obtaining determination coefficients at a level from 0.96 to 0.98 .

\section{Discussion}

The presented results correspond with the trend of limnological research concerning issues related to the thermal regime of lakes. As signalled in the introduction, studies based on a high degree of detail (hourly, minutes) of record of the data should be still considered as deficient. In reference to the current research of thermal regime of surface waters in Polish lakes with such frequency of temperature records, the paper by Skowron and Piasecki (2016) deserves particular attention. The study concerns 19 lakes. The authors determined among others that daily temperature fluctuations both in temporal and spatial distribution were variable. The highest water temperature fluctuations occurred in the period of spring warming, and frequently reached $4-5^{\circ} \mathrm{C}$, whereas in the remaining periods of the annual cycle, they rarely exceeded $2^{\circ} \mathrm{C}$. The study suggests that Lake Kierskie responded in a similar way where the spring period was characterised by the highest dynamics of changes. In the case of Poland, mountain lakes are specific. Choiński and Strzelczak (2018) analysed amplitudes of water temperature fluctuations in Lake Morskie Oko (1 $\mathrm{m}$ depth). The results show that in the near-surface layer they reach values of up to $3.5^{\circ} \mathrm{C}$, and were also observed in spring. Similarly as in the presented paper, the authors evidenced that water temperature showed stronger correlations with air temperature in comparison to correlations with wind speed. Water transparency is important for the distribution of water temperature in its surface layer. Water transparency is an approximate indicator of penetration of solar radiation into water, determined by the presence of solid particles that either absorb or disperse solar radiation reaching water (Osuch et al. 2016). It is particularly important in the daily cycle, as reflected in the dynamic increase in water temperature resulting from solar radiation. Lakes with lower water transparency absorb solar radiation in the shallower water layer, translating into its faster heating (Ptak et al. 2018b).

Research conducted by Provincial Inspectorate for Environmental Protection in Poznań in 2011 showed that the transparency of the analysed lake was $2 \mathrm{~m}$. The performed assessment of uniform parts of water showed bad state. High doses of natural fertilisers and disorganised sewage management is unfavourable for lakes, because it leads to an increase in the amount of the supplied biogenic substances (Zbierska et al. 2016). The direct catchment of Lake Kierskie is strongly transformed by man. Such areas constitute $63.8 \%$ of its surface area. This type of land use in the catchment is a double threat to the lake. It affects the concentration of nutrients in the lake, on the one hand with supplied sewage from anthropogenically transformed areas, and on the other hand that from overland flow (Brodzińska et al. 2009). The situation of excessive supply of biogenic substances in the catchment can be magnified by the fact that in the major part anthropogenically transformed areas are in direct contact with the lake. In this context, the lake is prone to considerable degradation, consequently leading to among others changes in the physical and chemical water parameters (including transparency), which in turn can contribute to a faster rate of increase in water temperature.

In the case of other regions of the world, research on thermal regime of lakes referring to daily fluctuations is becoming increasingly common (Frempong 1983, Spigel et al. 1986, Wilhelm et al. 2006, Andersen et al. 2017, Frassl et al. 2018). Comparable research on daily water temperature fluctuations between mutually neighbouring lakes was conducted by among others Woolway et al. (2015). The study shows that the size of the temperature cycle is particularly affected by the depth of the uppermost mixed layer. The authors observed a significant correlation between the range of daily fluctuations and the surface area of the lake. The lake analysed in the paper is the largest in the region in terms of surface area. Therefore, its response to the effect of wind will be manifested in later development of thermal stratification.

As emphasised by Woolway et al. (2016), knowledge on daily temperature fluctuations is important for the calculation of biochemical reactions and streams of gases. Research concerning 
$p \mathrm{CO}_{2}$ and $\mathrm{CO}_{2}$ by Yang et al. (2019) showed that water temperature is one of the primary factors affecting their daily dynamics. Therefore, they are issues important for the functioning of lake ecosystems, particularly in the context of transformations of the thermal regime of lakes (Woolway et al. 2017, Ptak et al. 2018b) under the conditions of climate changes. In this context, it is necessary to have detailed knowledge on all components affecting the lake ecosystem - their dynamics and scale of changes in different time scales.

\section{Conclusions}

Multi-annual hourly measurements of water temperature in Lake Kierskie permitted performing detailed characteristics of the parameter. Its daily and seasonal distribution is typical of lakes of moderate latitudes, and is comparable to that in other papers analysing the issue. In the monthly cycle, average temperature fluctuations were from more than $0.2^{\circ} \mathrm{C}$ (January, December) to $2.6^{\circ} \mathrm{C}$ (May). In reference to particular days it was determined that the maximum changes equalled $6.1^{\circ} \mathrm{C}$. Water temperature fluctuations, however, are usually low, and do not exceed $1^{\circ} \mathrm{C}$. In the case of wind, its effect was less substantial, and depending on the month, the strongest correlations with water temperatures were observed with an advance from 3 to 24 hours. Satisfactory prediction of water temperatures in the lake (with a threehour time step) is not possible based on air temperatures and wind speed. The obtained multiple regression models were characterised by weak adjustment. The research on the thermal regime of Lake Kierskie is the first study of the type for the lake. Importantly, the currently observed situation will provide the basis for further research, both in the context of the observed climate changes and the increasing human pressure (Ptak et al. 2013).

\section{Acknowledgments}

The authors wish to thank anonymous reviewers for their valuable suggestions and corrections.

\section{Authors' contribution}

Mariusz Ptak - 40\%, Mariusz Sojka - 35\%, Bogumił Nowak $25 \%$.

\section{References}

Andersen M.R., Sand-Jensen K., Woolway I.R., Jones, I.D., 2017. Profound daily vertical stratification and mixing in a small, shallow, wind-exposed lake with submerged macrophytes. Aquatic Sciences 79: 395-406. DOI: 10.1007/ s00027-016-0505-0.

Austin J.A., Colman S.M., 2007. Lake Superior summer water temperatures are increasing more rapidly than regional temperatures: A positive ice-albedo feedback. Geophysical Research Letters 34: 125-141. DOI: 10.1029/2006GL029021.

Brodzińska B., Grześkowiak A., Kornaś M., Nowak B., Żak, J., 2009. Zagrożenia dla jakości wód jeziornych. In: A.Grześkowiak, J.Żak (eds.), Jezioro Kierskie. Zagrożenia $i$ ochrona wód: 51-52). Instytut Meteorologii i Gospodarki Wodnej, Poznań.

Choiński A., Ptak M., Strzelczak A., 2015. Changeability of accumulated heat content in alpine-type lakes. Polish Journal of Environmental Studies 4(6): 2363-2369. DOI: 10.15244 /pjoes/58871.

Choiński A., Strzelczak A., 2018. Variability of short-term diel water temperature amplitudes in a mountain lake. Water 10(6): 795. DOI: 10.3390/w10060795.

Coloso J.J., Cole J.J., Pace, M.L., 2011. Short-term variation in thermal stratification complicates estimation of lake metabolism. Aquatic Sciences 73(2): 305-315. DOI: 10.1007/ s00027-010-0177-0.

Czernecki B., Ptak M., 2018. The impact of global warming on lake surface water temperature in Poland - the application of empirical-statistical downscaling. 1971-2100. Journal of Limnology 77(2): 330-348. DOI: 10.4081/jlimnol.2018.1707.

Frassl M.A., Boehrer B., Holtermann P.L., Hu W., Klingbeil K., Peng Z., Zhu J., Rinke., 2018. Opportunities and Limits of Using Meteorological Reanalysis Data for Simulating Seasonal to Sub-Daily Water Temperature Dynamics in a Large Shallow Lake. Water 10: 594. DOI: 10.3390/ w10050594.

Frempong E., 1983. Diel aspects of the thermal structure and energy budget of a small English lake. Freshwater Biology 13: 89-102. DOI: 10.1111/j.1365-2427.1983.tb00660.x.

Grześkowiak A., Szymański K., 2009. Charakterystyka misy jeziornej. In: A.Grześkowiak, J.Żak (eds.), Jezioro Kierskie. Zagrożenia i ochrona wód: 23-26, Instytut Meteorologii i Gospodarki Wodnej, Poznań.

Hampton S.E., Izmest'eva L.R., Moore M.V., Katz S.L., Dennis B., Silow E.A., 2008. Sixty years of environmental change in the world's largest freshwater Lake - Lake Baikal, Siberia. Global Change Biology 14: 1947-1958. DOI: 10.1111/j.1365-2486.2008.01616.x.

Jeppesen E., Mehner, T., Winfield, I.J., Kangur K., Sarvala J., Gerdeaux D., Rask M., Malmquist H.J., Holmgren K., Volta P., Romo S., Eckmann R., Sandström A., Blanco S., Kangur A., Stabo H.R., Tarvainen M., Ventelä A-M, Søndergaard M., Lauridsen T.L., Meerhoff M., 2012. Impacts of climate warming on the long-term dynamics of key fish species in 24 European lakes. Hydrobiologia 694: 1-39. DOI: $10.1007 / \mathrm{s} 10750-012-1182-1$.

Magee M. R., Wu C. H., 2017. Response of water temperatures and stratification to changing climate in three lakes with different morphometry. Hydrology and Earth System Sciences 21: 6253-6274. DOI: 10.5194/hess-21-6253-2017.

Martinsen K. T., Andersen M. R., Sand-Jensen K., 2019. Water temperature dynamics and the prevalence of daytime 
stratification in small temperate shallow lakes. Hydrobiologia 826 (1): 247-262. DOI: 10.1007/s10750-018-3737-2.

Mooij W.M., De Senerpont Domis L.N., Hülsmann S., 2008. The impact of climate warming on water temperature, timing of hatching and young-of-the-year growth of fish in shallow lakes in the Netherlands. Journal of Sea Research 60: 32-43. DOI: 10.1016/j.seares.2008.03.002.

Naumenko M.A., Guzivaty V.V., Karetnikov S.G., 2006. Climatic trends of the water surface temperature in Lake Ladoga during ice-free periods. Doklady Earth Sciences 409: 750-753.

Osuch E., Osuch A., Podsiadłowski S., Rybacki P., Adamski M., Ratajczak J., 2016. Assessment of the condition of Samołęskie Lake waters. Journal of Ecological Engineering 17(2): 108-112. DOI: 10.12911/22998993/62297.

Ptak M., 2018. Long-term temperature fluctuations in rivers of the Fore-Sudetic region in Poland. Geografie 123(3): 279-294.

Ptak M., Choiński A., Strzelczak A., Targosz A., 2013. Disappearance of Lake Jelenino since the end of the XVIII century as an effect of anthropogenic transformations of the natural environment. Polish Journal of Environmental Studies 22(1): 191-196.

Ptak M., Nowak B., 2016. Variability of oxygen-thermal conditions in selected lakes in Poland. Ecological Chemistry and Engineering $S$ 23(4): 639-650. DOI: 10.1515/eces-20160045.

Ptak M., Sojka M., Choiński A., Nowak B., 2018b. Effect of environmental conditions and morphometric parameters on surface water temperature in Polish lakes. Water 10(580). DOI: 10.3390/w10050580.

Ptak M., Sojka M., Kałuża T., Choiński A., Nowak B., 2019. Long-term water temperature trends of the Warta River in the years 1960-2009. Ecohydrology \& Hydrobiology, DOI: 10.1016/j.ecohyd.2019.03.007

Ptak M., Sojka M., Kozłowski M., 2019. The increasing of maximum lake water temperature in lowland lakes of Central Europe: case study of the Polish Lakeland. Annales de Limnologie - International Journal of Limnology 55(6): 11. DOI: 10.1051/limn/2019005.

Ptak M., Tomczyk A. M., Wrzesiński D., 2018a. Effect of teleconnection patterns on changes in water temperature in Polish lakes. Atmosphere 9(66): 1-17. DOI:10.3390/atmos9020066.

Ptak M., Wrzesiński D., Choiński A., 2017. Long-term changes in the hydrological regime of high mountain lake Morskie Oko (Tatra Mountains, Central Europe). Journal of Hydrology and Hydromechanics 65(2): 146-153. DOI: 10.1515/johh-2017-0005.
Schneider P., Hook S.J., 2010. Space observations of inland water bodies show rapid surface warming since 1985. Geophysical Research Letters 37: 208-217. DOI: 10.1029/2010GL045059.

Skowron R., Piasecki A., 2016. Dynamics of the daily course of water temperature in Polish lakes. Journal of Water and Land Development 31: 149-156. DOI: 10.1515/jwld-20160046.

Spigel R.H., Imberger J., Rayner K.N., 1986. Modeling the diurnal mixed layer. Limnology and Oceanography 31(3): 533-556. DOI: 10.4319/lo.1986.31.3.0533.

Wilhelm S., Hintze T., Livingstone D.M., Adrian R., 2006. Long-term response of daily epilimnetic temperature extrema to climate forcing. Canadian Journal of Fisheries and Aquatic Sciences 63(1): 2467-2477. DOI: 10.1139/f06-140.

Woolway R. I., Meinson P., Nõges P., Jones I. D., Laas A., 2017. Atmospheric stilling leads to prolonged thermal stratification in a large shallow polymictic lake. Climatic Change 141: 759-773. DOI: 10.1007/s10584-017-1909-0.

Woolway R.I, Jones I.D., Feuchtmayr H., Maberly S.C., 2015. A comparison of the diel variability in epilimnetic temperature for five lakes in the English Lake District. Inland Waters 5(2): 139-154. DOI: 10.5268/IW-5.2.748.

Woolway R.I., Dokulil M.T., Marszelewski W., Schmid M., Bouffard D., 2017. Warming of Central European lakes and their response to the 1980s climate regime shift. Climatic Change 42: 505-520. DOI: 10.1007/s10584-017-19664.

Woolway R.I., Jones I.D., Maberly S.C., French J.R., Livingstone D.M., Monteith D.T., Simpson G.L., Thackeray S.J., Andersen M.R., Battarbee R.W., Degasperi C.L., Evans C.D., Eyto E.D., Feuchtmayr H., Hamilton D.P., Kernan M., Krokowski J., Rimmer, A., Rose K.C., Rusak J.A., Ryves D.B., Scott D.R., Shilland E.M., Smyth R.L., Staehr P.A., Thomas, R., Waldron S., Weyhenmeyer G.A., 2016. Diel surface temperature range scales with lake size. PLoS ONE 11(3): Article number e0152466. DOI: 10.1371/ journal.pone.0152466.

Yang R., Xu Z., Liu S., Xu Y.J., 2019. Daily $p$ CO2 and CO2 flux variations in a subtropical mesotrophic shallow lake. Water Research 153: 29-38. DOI: 10.1016/j.watres.2019.01.012.

Zbierska A., Przybyła C., Dwornikowska Ż., 2016. Seasonal variability of selected nutrients in the waters of lakes Niepruszewskie, Pamiątkowskie and Strykowskie. Journal of Ecological Engineering 17(4): 129-137. DOI: $10.12911 / 22998993 / 63968$.

Zhu S., Nyarko E.K., Hadzima-Nyarko M., 2018. Modelling daily water temperature from air temperature for the Missouri River. PeerJ 6: e4894. DOI: 10.7717/peerj.4894. 